\title{
Small but Viscious: The Subclavius Posticus Muscle
}

\author{
Pequeño pero Vicioso: El Músculo Subclavius Posticus
}

\author{
Asha Gopalakrishnan ${ }^{1}$; Salini Dharmadas ${ }^{1}$; Tintu Thottiyil Sukumaran ${ }^{1}$; Swapna Ramakrishnan ${ }^{1} \&$ Minnie Pillay $^{1,2}$
}

GOPALAKRISHNAN, A.; DHARMADAS, S.; SUKUMARAN, T. T.; RAMAKRISHNAN, S. \& PILLAY, M. Small but viscious: The subclavius posticus muscle. Int. J. Morphol., 39(6):1596-1599, 2021.

SUMMARY: Accessory muscles of the neck are rare and are of clinical significance when present. During routine dissection of head and neck, two accessory muscles were found in the neck region of two cadavers, both male, one on the right and the other on the left. Both muscles took origin from the superior margin of the scapula and the insertion of the first muscle was to the clavicle, merging with subclavius and the second muscle got inserted to the first rib near the costochondral junction. This paper highlights the clinical significance and embryological aspects of such accessory muscles in the neck region.

KEY WORDS: Subclavius posticus muscle; Variation; Thoracic outlet syndrome.

\section{INTRODUCTION}

Presence of accessory muscles in the neck region are noteworthy for clinicians especially head and neck surgeons as they are likely to often obstruct the diagnosis and surgical procedures of various clinical conditions. In this context, two accessory muscles referred to as subclavius posticus (SP) encountered during routine dissection for teaching undergraduate students are highlighted in this paper. SP an aberrant muscle first described by Rosenmuller in 1800 (Akita et al., 2000) and reported by many others later is usually described as having proximal attachment to the first rib or its costal cartilage and distal attachment to the superior margin of scapula or transverse scapular ligament. Interestingly the muscles described here resembles subclavius posticus but with a slightly variant anatomy. Both the specimens had normal inferior belly of omohyoid and subclavius muscles.

\section{CASE REPORTS}

Case 1. An aberrant muscle was noted in the supraclavicular triangle of the neck region on the right side of a 72 year old male cadaver. The muscle had its origin from the superior margin of scapula adjoining the suprascapular ligament, just lateral to the origin of inferior belly of omohyoid muscle, after which it traversed the lower part of posterior triangle, superficial to the suprascapular nerve and brachial plexus.
Soon the muscle fibres transformed into a small aponeurosis of about $3 \mathrm{~cm}$ breadth which fused with the fascia covering subclavius (Fig. 1). A twig from the suprascapular nerve provided the nerve supply.

Case 2. An accessory muscle similar to the first case was noted in the left supraclavicular region of a 58 year old male cadaver. The muscle took origin from the lateral $2 / 3$ of the superior margin of scapula deep to the triangular origin of inferior belly of omohyoid muscle and traversed superficial to the structures in the subclavian triangle and inserted to the superior surface of $1 \mathrm{st}$ rib one inch lateral to the costochondral junction (Fig. 2). This muscle too was innervated by suprascapular nerve.

\section{DISCUSSION}

Observations by several authors on the presence of SP, discloses the fact that all of them have a common extent between the superior margin of the scapula and 1st rib and all are innervated either by suprascapular nerve, (Sarikcioglu \& Sindel, 2001; Forcada et al., 2006) nerve to subclavius, (Shetty et al., 2006) branches arising from ansa cervicalis (Akita et al.) or even accessory phrenic nerve. The prevalence of SP muscle ranges from $4.8 \%$ to $8.9 \%$ (Shetty et al.) and in more than $90 \%$ cases it is unilateral. Bilateral cases have

\footnotetext{
${ }^{1}$ Lecturer.

${ }^{2}$ Department of Anatomy, Amrita School of Medicine, Amrita Vishwa Vidyapeetham, Kochi-682041, Kerala, India.
} 


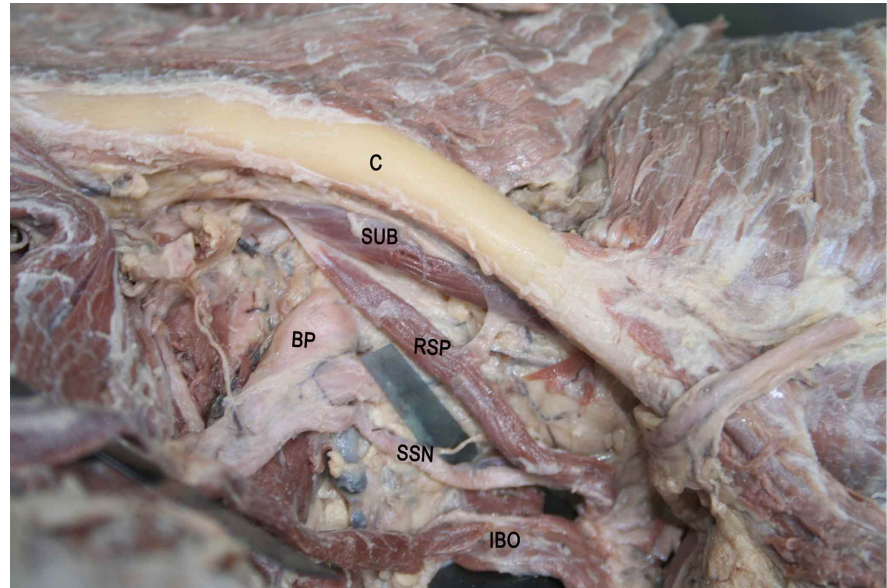

Fig. 1. Dissection revealing the right subclavius posticus (RSP) muscle in the supraclavicular region. C - Clavicle, SUB - Subclavius, RSP Right subclavius posticus, BP - Brachial plexus, SSN - Supra scapular Nerve, IBO - Inferior belly of omohyoid muscle.

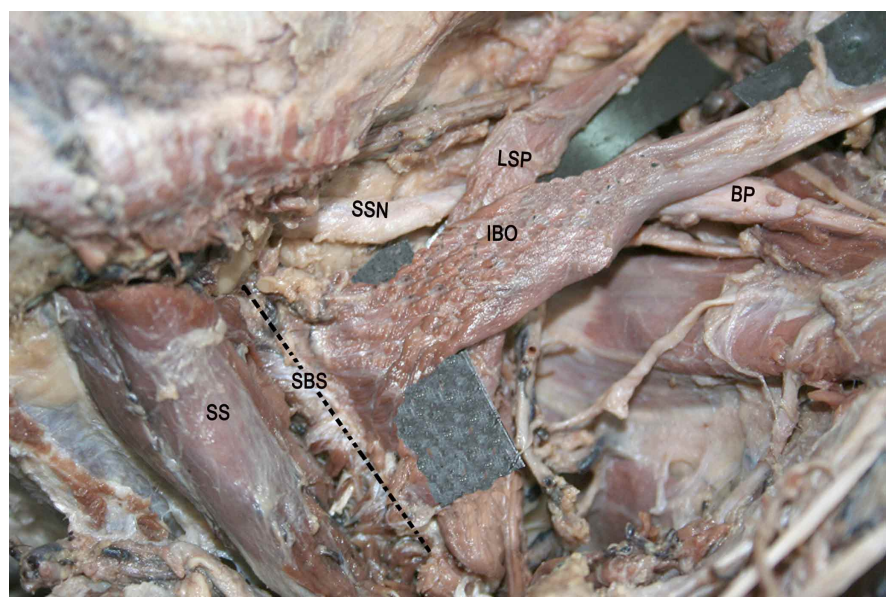

Fig. 2. Dissection revealing the left subclavius posticus (LSP) muscle in the supraclavicular region, Superior view. LSP - Left subclavius posticus, BP - Brachial plexus, SSN - Supra scapular nerve, SBS Superior margin of scapula, SS - Supraspinatus muscle, IBO - Inferior belly of omohyoid muscle.

a prevalence of $1.7 \%$ as reported by Ulusoy et al. (2018) in a radiological study conducted on 350 patients in 2018 .

Neck muscles are collectively referred to as hypobranchial and cucullaris muscle groups (Sambasivan et al., 2011). These muscle groups are derived from occipital somites and some from cervical somites (Birchmeier \& Brohmann et al., 2000). It has been hypothesized that in Wistar rats subclavius muscle develops from the region between hypobranchial and pectoral regions of the trunk. With the development of heart and lungs, these regions undergo significant changes phylogenitically and ontogenitically to which variations and innervations of this muscle are attributed (Shetty et al.). According to Diwan et al. (2014) anomalous differentiation of primary pectoral muscle could be responsible for variations of subclavius muscle. Explanations detailing the ontogenesis of this muscle are sparse and variably reported in literature. Studies on animal models explain the SP muscle as a rudiment of hypobranchial musculature between the hypobranchial and pectoral regions at midline. According to Tountas \& Bergman (1993) these accessory muscles are derived from the 5 th cervical to 1 st thoracic myotomes.

Aberrant SP muscles have been reported by several authors (Sarikcioglu \& Sindel; Forcada et al.; Shetty et al.; Singhal et al., 2008; Cogar et al., 2015). Kutoglu et al. (2005) reported a case of SP, which got inserted to upper margin of scapula just inferior to the insertion of the inferior belly of the omohyoid muscle. Moyano et al. (2018) found an aberrant SP muscle with insertion to the 1 st costal cartilage and then the muscle was found crossing the brachial plexus and subclavian vessels, similar to our second case, but had attachment to the posterior surface of serratus anterior muscle. In 2004 an anomalous omohyoid muscle originating from the transverse process of C6 vertebra and inserting to scapula was studied by Tubbs et al. (2004). Piyawinijwong \& Sirisathira (2010) explored abnormal subclavius muscle with a wide insertion extending along the inferior surface of the clavicle, conoid ligament, coracoid process, superior transverse scapular ligament to the superior margin of scapula.

Diwan et al., (2014) reported a case of subclavius muscle with an accessory belly designated as subclavius anticus which is attached to the coracoid process, axillary sheath and fascia covering subscapularis muscle. Some fibres of this muscle also had attachment to transverse scapular ligament and adjoining area of the superior margin of scapula just medial to suprascapular notch.

Thoracic outlet syndrome (TOS) is a group of disorders secondary to compression of blood vessels or nerves in the thoracic outlet. Anomalous or hypertropied muscles in the neck are one among the several factors enumerated in the etiology of TOS. Hence there is a need for familiarising with the, possible variations, and relations of accessory muscles to neurovascular structures in the subclavian triangle. The presence of aberrant muscles in the neck region can cause difficulty in accessing structures like cervical lymph nodes and other neurovascular elements in various surgical procedures of neck region including block dissection of the neck (Raikos et al., 2012). Depending on the structures compressed, the thoracic outlet syndrome can be classified as either vascular or neurogenic. The close proximity of neurovascular structures in the neck region 
limits a clear cut classification of TOS to vascular or neurogenic. Of the large number of reported cases of TOS approximately $95 \%$ are estimated to be neurogenic.

Abnormal pressure caused by accessory subclavius muscle on brachial plexus and its branches can cause pain and discomfort in upper limb (Laulan et al., 2011; Grigorita et al., 2018). Paget Schrotter syndrome refers to thrombosis of subclavian vein resulting from venous compression. Compression of subclavian vein in the region can result in oedema or cyanosis of upper limb. SP muscle in the extreme abducted position of the arm is reported to compress subclavian vein resulting in Paget Schrotter syndrome (Mall et al., 2013).

Arterial complications in TOS involving SP muscle is rarely reported in literature. Those studies mentioning arterial involvement pertains mainly to the presence of an abnormal bone or anomalous scalene muscle (Levine \& Rigby, 2018). The association of muscle with etiology of Paget-von Schroetter syndrome, brachial plexopathy and suprascapular neuropathy was reported by Ulosoy et al., in 2018.

The relation of muscle with neurovascular structures in the neck makes it a potential source of compression of these structures. This necessitates the need for awareness of the presence, development and clinical significance of this muscle while dealing with patients with thoracic outlet syndrome, or with symptoms of venous compression.

\section{CONCLUSION}

SP muscles found in random cases could be due to phylogenetic retention. But when present, it is found crossing the neurovascular structures in neck. Knowledge of the presence of SP muscle in the subclavian triangle is of paramount importance to the head and neck surgeons and radiologists as it helps in developing strategic treatment plan and to conduct surgeries of the neck region.

\section{GOPALAKRISHNAN, A.; DHARMADAS, S.;} SUKUMARAN, T. T.; RAMAKRISHNAN, S. \& PILLAY, M. Pequeño pero visible: El músculo subclavius posticus. Int. J. Morphol., 39(6):1596-1599, 2021.

RESUMEN: Los músculos accesorios del cuello son infrecuentes y tienen importancia clínica cuando están presentes. Durante la disección de rutina de la cabeza y el cuello, se encontraron dos músculos accesorios en la región del cuello de dos cadáveres, ambos de sexo masculino, uno a la derecha y otro a la izquierda. Ambos músculos se originaban en el margen superior de la escápula y la inserción del primer músculo se extendía a la clavícula, fusionándose con el músculo subclavio. El segundo músculo se insertó en la primera costilla cerca de la unión costocondral. Este artículo destaca la importancia clínica y los aspectos embriológicos de dichos músculos accesorios en la región del cuello.

PALABRAS CLAVE: Músculo subclavio posticus; Variación; Síndrome de la salida torácica.

\section{REFERENCES}

Akita, K.; Ibukuro, K.; Yamaguchi, K.; Heima, S. \& Sato, T. The subclavius posticus muscle: a factor in arterial, venous or brachial plexus compression. Surg. Radiol. Anat., 22(2):111-5, 2000.

Birchmeier, C. \& Brohmann, H. Genes that control the development of migrating muscle precursor cells. Curr. Opin. Cell Biol., 12(6):725-30, 2000 .

Cogar, A. C.; Johnsen, P. H.; Potter, H. G. \& Wolfe, S. W. Subclavius posticus: an anomalous muscle in association with suprascapular nerve compression in an athlete. Hand (N. Y.), 10(1):76-9, 2015.

Diwan, R. K.; Chopra, J.; Anitarani.; Rani Archana; Sehgal Garima \& Srivastava, A. K. A rare variation of subclavius muscle. J. Anat. Sci., 22(2):22-5, 2014.

Forcada, P.; Rodríguez-Niedenführ, M.; Llusá, M. \& Carrera, A. Subclavius posticus muscle: supernumerary muscle as a potential cause for thoracic outlet syndrome. Clin. Anat., 14(1):55-7, 2001.

Grigorita, L.; Vaida, M. A. \& Jianu, A. An aberrant subclavius posticus muscle: a case report. Med. Princ. Pract., 27(6):579$81,2018$.

Kutoglu, T.; Ulucam, E \& Gurbuz, H. A case of the subclavius posticus muscle. Trakia J. Sci., 3(1):77-8, 2005.

Laulan, J.; Fouquet, B.; Rodaix, C.; Jauffret, P.; Roquelaure, Y. \& Descatha, A. Thoracic outlet syndrome: definition, aetiological factors, diagnosis, management and occupational impact. $J$. Occup. Rehabil., 21(3):366-73, 2011.

Levine, N. A. \& Rigby, B. R. Thoracic outlet syndrome: biomechanical and exercise considerations. Healthcare (Basel), 6(2):68, 2018.

Mall, N. A.; Van Thiel, G. S.; Heard, W. M.; Paletta, G. A.; BushJoseph, C. \& Bach Jr., B.R. Paget-Schroetter syndrome: a review of effort thrombosis of the upper extremity from a sports medicine perspective. Sports Health, 5(4):353-6, 2013.

Moyano, P. J.; Capurro, M.; Apa, S. N. \& Albanese, E. F. Subclavius posticus muscle with anomalous posterior insertion: case report. Int. J. Morphol., 36(1):22-5, 2018.

Piyawinijwong, S. \& Sirisathira. Supernumerary subclavius muscle in Thais: predisposing cause of thoracic outlet syndrome. J. Med. Assoc. Thai., 93(9):1065-8, 2010.

Raikos, A.; Paraskevas, G. K.; Triaridis, S.; Kordali, P.; Psillas, G. \& Brand-Saberi, B. Bilateral supernumerary sternocleidomastoid heads with critical narrowing of the minor and major supraclavicular fossae: clinical and surgical implications. Int. J. Morphol., 30(3):927-33, 2012.

Sambasivan, R.; Kuratani, S \& Tajbakhsh, S. An eye on the head: the development and evolution of craniofacial muscles. Development, 138(12):2401-15, 2011 
Sarikcioglu, L. \& Sindel, M. A case with subclavius posticus muscle. Folia Morphol. (Warsz.), 60(3):229-31, 2001.

Shetty, Y. P.; Pai, M. M.; Prabhu, L. V.; Vadgaonkar, R.; Nayak, S. R. \& Shivanandan, R. The subclavius posticus muscle: its phylogenetic retention and clinical relevance. Int. J. Morphol., 24(4):599-600, 2006.

Singhal, S.; Rao, V. V. \& Manjunath, K. Y. Subclavius posticus muscle - A case report. Int. J. Morphol., 26(4):813-5, 2008.

Tountas, C. \& Bergman, R. Anatomic Variations of the Upper Extremity. New York, Churchill Livingstone, 1993. pp.223-4.

Tubbs, R. S.; Salter, E. G. \& Oakes, W. J. Unusual origin of the omohyoid muscle. Clin. Anat., 17(7):578-82, 2004.

Ulusoy, O. L.; Alis, D.; Oz, A.; Barlas, S. B.; Sokmen, B. K.; Sever, S.; Mutlu, A. \& Colakoglu, B. The prevalence and characteristics of the subclavius posticus muscle in the adult population on MRI. Surg. Radiol. Anat., 40(10):1141-5, 2018.
Corresponding author:

Dr. Minnie Pillay, $\mathrm{PhD}$

ORCID - 0000-0002-2046-7359

Professor and Head, Department of Anatomy

Amrita School of Medicine

Amrita Vishwa Vidyapeetham

Kochi-682041

Kerala

INDIA

E-mail: minniepillay@aims.amrita.edu

Received: 06-07-2021

Accepted: 27-09-2021 